NBER WORKING PAPER SERIES

COORDINATION IN THE EUROPEAN UNION

Martin Feldstein

Working Paper 18672

http://www.nber.org/papers/w18672

\author{
NATIONAL BUREAU OF ECONOMIC RESEARCH \\ 1050 Massachusetts Avenue \\ Cambridge, MA 02138 \\ January 2013
}

The views expressed herein are those of the author and do not necessarily reflect the views of the National Bureau of Economic Research.

NBER working papers are circulated for discussion and comment purposes. They have not been peerreviewed or been subject to the review by the NBER Board of Directors that accompanies official NBER publications.

(C) 2013 by Martin Feldstein. All rights reserved. Short sections of text, not to exceed two paragraphs, may be quoted without explicit permission provided that full credit, including $(\mathbb{C}$ notice, is given to the source. 
Coordination in the European Union

Martin Feldstein

NBER Working Paper No. 18672

January 2013

JEL No. F0,F02,F15,F3,F4,F5

\begin{abstract}
$\underline{\text { ABSTRACT }}$
This paper examines the sources of current conflict within the EU and the EMU. The topics discussed include the recent ECB policy of bond buying (the OMT policy), the attempts to advance the "European Project" of stronger political union (the fiscal compact, the banking union, and the proposals for budget supervision). Contrary to the claims of the European leadership, the progress that has been made has been by individual countries and not by coordinated action. The special problems of France and Britain are also discussed.
\end{abstract}

\author{
Martin Feldstein \\ Professor of Economics, \\ Harvard University \\ and \\ NBER \\ 1050 Massachusetts Avenue \\ Cambridge, MA 02138-5398 \\ msfeldst@nber.org
}




\title{
Coordination in the European Union
}

\author{
Martin Feldstein*
}

The European Union recently received the Nobel Peace Prize for achieving "peace and cooperation" in Europe. In accepting the prize, Jose Manuel Barroso, the President of the European Commission, said that the European Union is "more than an association of states. It is a new legal order, which is not based on the balance of power between nations but on the free consent of states that share sovereignty."

This should be a framework within which there would be cooperation and the coordination of economic policies. But anyone following the events in Europe during the past two years recognizes that the Nobel Peace Prize came at a time when acrimony among the European Union's members has not been greater since the Union began.

The conflict is greatest at the core of the EU, in the Economic and Monetary Union whose 17 members use the euro as their single currency. That conflict now focuses on the willingness of Germany to provide aid to Greece and potentially to Spain and Italy, and on the conditions that Germany would demand in exchange for that aid.

Greece is small and the provision of aid through the forgiveness of debt and the support of Greek banks is an irritant to Germany rather than a substantial

\footnotetext{
* Professor of Economics, Harvard University. These remarks were prepared for presentation on January 5, 2013 at the meeting of the American Economic Association. For earlier and more general discussion of the European Union and the Economic and Monetary Union see Feldstein (1992, 1997a, b and 2011a).
} 
burden. But Spain and Italy are large, with a combined GDP that exceeds that of Germany.

Anyone who talks with personal friends or government officials in Greece, Italy or Spain hears their bitter complaints that Germany is seeking to impose its will and its values on its Latin neighbors. Germany is criticized as a hegemonic power that is trying to achieve through political and financial means what it failed to achieve in World War II. And conversations in Germany turn quickly to the failure of the Latin countries to fix their economies and reform their lifestyles.

\section{The ECB and the OMT Policy}

Despite this bickering, there have been policy changes. The European Central Bank recently voted to buy short-term government bonds of both Spain and Italy if they apply for aid and agree to conditions worked out with the European Commission and the IMF. This policy was enigmatically dubbed the Outright Monetary Transactions programme, or OMT, perhaps to counter the more obvious interpretation that the combination of budget conditionality and government bond buying is really a fiscal policy program. OMT has already reduced the long-term interest rates in both Spain and Italy even before any of the contemplated actions have occurred.

Nothing more may happen under OMT unless there is a renewed financial crisis. The governments in Spain and Italy are reluctant to accept imposed conditionality in exchange for financial help. And the German public is unhappy 
about transferring funds to these neighbors since, in the case of a default, some 40 percent of the losses incurred by the ECB would be born by Germany.

So although a lending mechanism is in place, neither the potential borrowers nor the German public want to see loans beginning to flow. So much for the most recent attempt at coordination of fiscal policy and Central Bank support. ${ }^{1}$

\section{Coping with the Eurozone Crisis}

The Eurozone crisis began in the spring of 2010 when the Greek government revealed that its national debt and deficits were much larger than they had previously admitted. That raised the possibility that Greece might default on its debt or that it might even leave the EMU.

The thought that an EMU country could default on its debt or might leave the EMU frightened international lenders who had previously believed that neither default nor exit was a possibility. They responded by refusing to buy Greek debt or indicating that they would do so only at extremely high interest rates. The result was a sharp rise in the interest rates on Greek government and private debt.

Investors then focused on the situation in Italy and Spain. The Italian government debt was more than 100 percent of Italy's GDP. Spanish sovereign debt was relatively less than that of Italy but was expected to rise as the Spanish government came to the rescue of its banks that had lent unwisely during the recent housing boom. Interest rates in Italy and Spain rose sharply to levels that caused large fiscal deficits and rising ratios of debt to GDP.

${ }^{1}$ For further comments on this action by the European Central Bank see Feldstein (2012a,b). 
Germany's Chancellor Angela Merkel and the EU officials in Brussels saw this crisis as an opportunity to advance the so-called "European project," i.e. an opportunity to move toward a tighter political union. They claimed, incorrectly, that the problems of these high debt countries could only be solved at the European level and not by each country acting alone. ${ }^{2}$

The European leaders saw the move toward political union in three steps: a fiscal compact to limit deficits and debt; a banking union to coordinate banking supervision and create a European program of deposit insurance; and finally a budget plan that would provide for greater transfers among countries and a greater control by the European Commission (under Germany's watchful eye) of the details of each country's budget.

Some called this a greater coordination of economic policies. Others criticized it as an attempt by Germany to impose its standards on the other countries. In practice, very little was achieved.

A Fiscal Compact was drafted and agreed to by the heads of the EU governments. It provides for annual limits on budget deficits and mandatory annual reductions in the ratio of national debt to GDP. There are potential penalties for countries that do not meet these standards. Angela Merkel and the Brussels officials declared that an important milestone toward political union had thus been achieved.

${ }^{2}$ For my contrary view at the time, see Feldstein (2011b). 
In practice, however, fiscal deficits in the member countries continue to exceed the specified limits and national debt ratios continue to rise. No penalties have been imposed. The exercise is reminiscent of the old Stability and Growth pact that was violated by Germany and France almost immediately after it had been agreed. That pact was then rewritten to make it totally ineffective. ${ }^{3}$

Although the Banking Union that was recently created provided political leaders with a new opportunity to say that Europe is moving closer to political union, its content is very limited. The European Central Bank will establish standards for Eurozone banks and can in principle supervise very large ones. In practice, however, even those large ones will be supervised as they are now by national central banks like the Bank of Italy and the German Bundesbank. Germany and others rejected the French proposal for a Eurozone system of deposit insurance because it would have caused the countries with strong banks to insure deposits in the countries with weak banks.

More recently, the officials in Brussels prepared an elaborate plan for controlling the content of the budgets of the member countries. There were however strong objections among EMU member countries to this loss of individual country sovereignty over national budgets. Discussion of the Brussels' plan was therefore postponed until future meetings.

${ }^{3}$ For comments on the fiscal compact, see Feldstein (2012c). I discussed the experience with the Stability and Growth Pact in Feldstein (2005). 
In short, the political leaders in Europe have talked about moving to political union and coordinating policies more closely but have done very little.

\section{Progress Country by Country}

The progress that has been made in dealing with the Eurozone's fiscal problems has been achieved country by country and not as a result of Eurozone coordination. The new Italian government under Mario Monti reduced current and future fiscal deficits by changing the retirement rules for the Social Security pension system and raising taxes on residential real estate. The IMF predicts that these actions mean that Italy will have a cyclically adjusted budget surplus in 2013 . Unfortunately, though, Italy is in recession and the actual budget will be in deficit.

Although Spain has made important improvements in the condition of its banks, the Spanish economy remains in very bad shape. The fiscal deficit is more than 7 percent of GDP and the unemployment rate exceeds 25 percent. Spain has a larger current account deficit than Italy. A critical problem is the constitutionally established relative autonomy of Spain's individual regions.

Greece, Ireland, and Portugal were forced to accept IMF programs. In the context of the IMF programs, those countries have taken actions to shrink their fiscal deficits. Once again, those actions were done unilaterally and not as the result of coordination within the Eurozone. 


\section{The Problem of France}

The French situation is unusual. France is on the edge of recession if not already in recession. Its fiscal deficit and its current account deficit are larger as shares of GDP than in Italy, its double-digit unemployment rate is similar to Italy's, and its major banks are believed to be undercapitalized and weighed down with bad assets. But despite all of this, the interest rate on French 10-year government debt is only about 60 basis points above Germany's while the interest rates on Italian and Spanish bonds exceed that on German bonds by 300 basis points for Italy and 400 basis points for Spain. The willingness of the international financial market to provide funds to France at relatively low interest rates may reflect France's relatively low debt to GDP ratio of about 80 percent or it may be a temporary situation that the markets will soon correct.

France has been more enthusiastic about the European project than any other country. The idea was initiated just after World War II by two French officials, Jean Monnet and Robert Schuman, who advocated the creation of a United States of Europe. French officials saw this as a way to make Europe a political power comparable to the United States and thereby to give France, with its sophisticated foreign service, an important role in European and world affairs.

French Finance Minister Jacques Delors successfully led the campaign for a single currency with a famous report based on the specious argument that the single European market for goods and services required a single currency ("One Market, One Money"). 
One of the real reasons for wanting the common currency was the idea that it would cause individuals to identify themselves more strongly as Europeans, providing support for the project of political integration.

Substituting the euro for national currencies would also require Germany to give up the Deutche Mark and to allow a European Central Bank to substitute for the dominant role of the Bundesbank. President Mitterand forced Germany to accept the euro by making that a condition for French support of German reunification.

The French pursuit of the European project has clearly failed to achieve what French political leaders wanted from the beginning. Instead of the amity and sense of purpose of which Monnet and Schuman dreamed, there is conflict and disarray. Europe's international role is shrinking, with the old G5 group having evolved into the G20. And with Germany's Chancellor Angela Merkel setting conditions for the Eurozone, France's ambition to dominate European policy has been thwarted. ${ }^{4}$

\section{Britain's Independent Role}

Britain is a special case of disharmony and of a desire to avoid the rules of the European Union and the Eurozone. Britain is a member of the European Union but not of the single currency. But even without the problems of the euro, there is widespread discontent in Britain with its membership in the European Union.

Part of Britain's unhappiness with its EU membership is a concern that France and others will try to use EU rules to undermine Britain's role as the leading financial center in Europe. But there is also a general feeling in Britain that the

\footnotetext{
${ }^{4}$ For a further discussion of this, see Feldstein (1997 and 2012d)
} 
British people are fundamentally different from continental Europeans in history, culture, religion, and other ways.

Prime Minister David Cameron has indicated that the Conservative party is likely to promise to hold a referendum on the nature of Britain's EU membership after the next election. He argues that, as other countries in the EU come closer together because of the single currency, Britain needs a more distant relation.

It is not clear that there can be a meaningful referendum on the ambiguous issue of changing Britain's role in Europe. Polls show that a majority of the British electorate would now choose to leave the European Union. The public support for leaving the EU is so strong that the Labor party is also expected to promise such a referendum if the election looks close. And if Britain does leave the EU, other countries including Finland and the Netherlands may follow.

Is the European Union Different?

As a general rule, attempts at policy coordination among countries have not succeeded. The exception is coordination of trade policies where there are clear gains and where the required action can be stated as a "Thou shall not."

But macroeconomic coordination through the G5 or G20 only appears to work when it is clearly in the self-interest of each country taken individually to do what is also good for the group as a whole. Although the G20 leaders proclaimed that the common response to the global downturn after 2007 was an example of successful coordination, there is no evidence that countries took monetary or fiscal actions that they would otherwise not have done in their own separate interest. 
The Eurozone countries have clearly gone further than policy coordination in giving up their individual currencies and their national central banks, accepting the ECB as the maker of a common monetary policy and accepting the common exchange rate. However, this is not a coordination of policy but a transfer of policy authority to a single supranational institution.

\section{$\underline{\text { A Euro Devaluation? }}$}

A major challenge that could be dealt with by coordinated action in the Eurozone is the large and persistent current account deficits of most Eurozone members. The obvious solution for any country in that situation, if it is not bound by a single currency, would be to devalue its currency, thus encouraging exports and the substitution of domestic goods and services for imported products.

Although the countries of the Eurozone cannot devalue individually, a coordinated strategy to reduce the value of the euro through statements and actions of the ECB would achieve that goal. A lower Euro would make each of the Eurozone countries more competitive relative to the countries outside the Eurozone.

While reducing fiscal deficits and improving labor and product markets must be done by each individual country, a currency realignment is a challenge that calls for coordinated action. It is interesting to ask why that has not occurred. Cambridge, MA

December 2012 


\section{$\underline{\text { References }}$}

Feldstein, Martin “The Case Against the Euro,” The Economist, 1992

“EMU and International Conflict, Foreign Affairs, 1997a

"The Political Economy of the European Economic and Monetary Union,"

Journal of Economic Perspectives, 1997b

“The Euro and the Stability Pact," The Journal of Policy Modeling, 2005

“The Failure of the Euro," Foreign Affairs, 2011a

"Italy Can Save Itself and the Euro," Financial Times, November 30, 2011b

“A Weaker Europe Will Help Solve Europe's Deficit Woes,” Financial Times,

December 19, 2011c

“Fed Joins ECB in High Risk Move," Financial Times, September 27, 2012a

"An Optimistic Case for the Euro," Project Syndicate, October 30, 2012b

“Europe’s Empty Fiscal Compact," Project Syndicate, February 27, 2012c

“France's Broken Dream," Project Syndicate, May 21, 2012d

“ A Weaker Euro Could Rescue Europe,” Wall Street Journal, January 27,

$2012 \mathrm{e}$ 